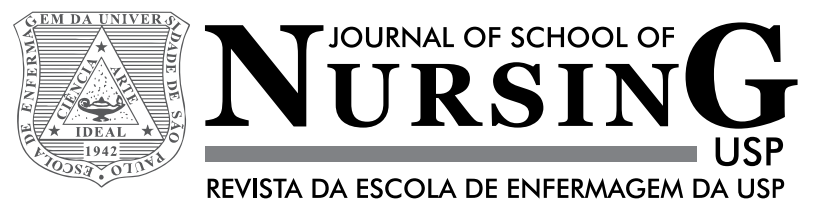

\title{
The quality and characteristics of sleep of hypertensive patients
}

\author{
Características e qualidade do sono de pacientes hipertensos \\ Características y calidad del sueño de pacientes hipertensos
}

Juliét Silveira Hanus ${ }^{1}$, Graziela Amboni ${ }^{1}$, Maria Inês da Rosa ${ }^{2}$, Luciane Bisognin Ceretta ${ }^{1}$, Lisiane Tuon ${ }^{3}$

\footnotetext{
${ }^{1}$ Universidade do Extremo Sul Catarinense, Programa de Residência Multiprofissional em Saúde Coletiva, Criciúma, SC, Brazil.

${ }^{2}$ Universidade do Extremo Sul Catarinense, Programa de Pós-Graduação em Ciências da Saúde, Criciúma, SC, Brazil.

${ }^{3}$ Universidade do Extremo Sul Catarinense, Centro Especializado em Reabilitação, Criciúma, $\mathrm{SC}$, Brazil.
}

\begin{abstract}
Objective: Analyzing the quality of sleep of hypertensive patients registered in the national registration system and monitoring of hypertensive patients. Methods: A cross-sectional study of quantitative and descriptive analyses with 280 hypertensive patients registered in the National Program of Hypertension and Diabetes of the Federal Government in the months from August to October 2011. Questionnaires were used which allowed for tracking sociodemographic data on hypertension and Pittsburgh Sleep Quality Index (PSQI). Results: The prevalence of poor sleep quality among respondents (156 hypertensive patients) and high rates of using medication for sleeping (106 hypertensive patients) was observed. Other relevant data refers to the quality of sleep among hypertensive patients using sleep medication compared to those who do not use it $(p \leq 0.01)$. Conclusion: Individuals with high blood pressure have a negative association with sleep quality.
\end{abstract}

DESCRIPTORS

Hypertension; Sleep; Sleep Apnea Syndromes; Public Health; Health Evaluation. 


\section{INTRODUCTION}

Hypertension or High Blood Pressure (HBP) is considered a non-transmissible chronic disease, and one of the major challenges for public health around the world ${ }^{(1)}$. It accounts for about $13 \%$ of all global deaths ${ }^{(2)}$. It affects approximately $25 \%$ of the world population, with a $60 \%$ increase of estimated cases by $2025^{(3)}$. It is a common condition strongly associated with cardiovascular morbidity and mortality ${ }^{(4)}$ with high social medical cost, affecting individuals in their productive stage of life ${ }^{(5)}$. Population studies show the prevalence of hypertension in Brazil from $22.3 \%$ to $43.9 \%(4,6-7)$.

Another disease with high morbidity in the population is the Obstructive Sleep Apnea Syndrome (OSAS), and it is estimated that approximately $40 \%$ of hypertensive patients and $80 \%$ of those with resistant hypertension have OSAS ${ }^{(8-9)}$ and about $55 \%$ individuals with OSAS have hypertension ${ }^{(10)}$.

In hypertensive patients, the prevalence of OSAS is higher than that found among the general population, and there is evidence that diagnosis is associated with concomitant hypertension. Thus, the need for combination treatment, especially in patients with resistant hypertension should be considered ${ }^{(11)}$.

Indicative factors that constitute pathophysiological mechanisms of hypertension ${ }^{(12)}$ closely related to the development of sleep disorders are: hyperactivity of the sympathetic nervous system and the renin-angiotensin system (RAS); increase in the relative endotelina1/nitric oxide; the use of recombinant erythropoietin; the presence of secondary hyperparathyroidism; and especially, the increase in extracellular volume ${ }^{(13-14)}$.

The quality of sleep and high blood pressure are strongly influenced by lifestyle, and individuals with hypertension are more likely to have sleep disorders ${ }^{(15)}$.

The most common sleep disorders are restless legs syndrome, insufficient amount of hours slept, insomnia, and obstructive sleep apnea, the latter being the most common disorder in hypertensive individuals ${ }^{(16)}$.
Therefore, understanding the quality of sleep in hypertensive individuals is essential to assist in the care planning of this aspect in this population. Research that characterizes the profile of hypertensive patients in relation to the quality of sleep are scarce. Some studies have already attributed some sleep disorder as the main factor leading to the development of hypertension. In this context, there is a gap in the literature that addresses hypertension as a causal factor of sleep disorders. This study aimed at evaluating quality of sleep of hypertensive individuals registered in the national registration system and monitoring of hypertensive patients.

\section{METHOD}

A cross-sectional, quantitative and descriptive study that included hypertensive individuals registered in the National Hypertension and Diabetes Program of the Federal Government in a southern city of Santa Catarina. In total, 782 hypertensive patients were registered. A simple random sample was calculated with a sampling error of $5 \%$ and 95\% significance level, which resulted in 258 hypertensive individuals. A $10 \%$ surplus to was estimated compensate for losses, totaling 284 elderly.

Inclusion criteria were: being over 18 years old, diagnosed with hypertension, registered at the health district, and being available at least once in the three attempts of home visits. Exclusion criteria were: not being registered in the health district, not being available at the time of the home visit.

Data were collected at participant's homes through a structured interview with questions related to socioeconomic data, clinical data and the Pittsburgh Index (PSQI), from August to October 2011.

To analyze socio-demographic profile, a questionnaire adapted from the Brazilian Institute of Geography and Statistics was designed.

Chart 1 shows the variables of interest of the study, composing the sociodemographic and clinical data of hypertensive patients.

Chart 1 - Variables of interest of the study - Criciúma, SC, Brazil, 2011.

\begin{tabular}{|l|l|}
\hline Characteristics & Variables \\
\hline Socioeconomic data & $\begin{array}{l}\text { age, gender, marital status, ethnicity, family income, education level, height, } \\
\text { weight, occupation, smoking and drinking habits. }\end{array}$ \\
\hline Clinical data & $\begin{array}{l}\text { Type and quantity of anti-hypertensive medication administered, time of hyperten- } \\
\text { sion diagnosis, systolic blood and diastolic blood pressure levels, type and amount } \\
\text { of medications prescribed for sleeping. }\end{array}$ \\
\hline
\end{tabular}

Data such as weight and height registered into the program`s health handbook were relative to the month when the medication to control hypertension was suspended, as participants were monitored monthly by the program. Blood pressure measurements were performed by trained researchers, before the start of the interviews. Sphygmomanometer (Premium) and Rappaport stethoscope (Premium) were used for the measurement of BP.

In order to investigate subjective sleep quality, we used the Pittsburgh Index (PSQI). The main purpose of this instrument is evaluating the subjective quality and the occur- rence of sleep disorders. The questionnaire consists of ten questions that form seven components: 1) Subjective sleep quality; 2) Sleep latency; 3) Sleep duration; 4) Habitual sleep efficiency; 5) Sleep disturbances; 6) Use of sleep medications; 7) Daytime disturbances. Each component can vary in a scale of 0 to 3 , where 0 indicates very good quality and 3 is very bad quality. The maximum score of the instrument is 21 points; a score $>5$ indicates that the patient is having great difficulties in at least two components or moderate difficulty in more than three components, thus, the higher the score, the worse the quality of sleep of the individual. 
Data were tabulated in Microsoft Excel and analyzed using the SPSS 18.0 statistical program for Windows. The Mann-Whitney U test and chi-square Pearson with $\mathrm{p} \leq 0.05$ were used. We also calculated the Odds Ratio as a measure of association, with a $95 \%$ confidence interval. The research project was approved by the Research Ethics Committee of Universidade do Extremo Sul Catarinense - UNESC number 194/2011. The ethical principles of voluntary and informed participation were observed for each subject, who spontaneously signed the Informed Consent Form, authorizing the application of instruments for data collection as recommended in Resolution No. 196/1996 of the National Health Council, effective on the date the study was approved by the Research Ethics Committee.

\section{RESULTS}

The descriptive analysis of the 280 hypertensive respondents allowed us to obtain the results presented below, mapping the sociodemographic profile of the study population (Table 1), data on hypertension of respondents (Table 2), medication for sleeping correlated with components of the PSQI instrument (Figure 1), and medication for sleeping correlated to total PSQI scores (Table 3).

Table 1 - Subjects distribution according to sociodemographic variables - Criciúma, SC, Brazil, 2011.

\begin{tabular}{lc}
\hline Variables & $\mathbf{n}(\mathbf{\%}) \mathbf{n = 2 8 0}$ \\
\hline Average age & $63.0( \pm 11.0)$ \\
Median & IC $(95 \%): 61.70-64.29$ \\
Gender & 64.0 \\
Male & \\
Female & $91(32.5)$ \\
Family Income & $189(67.5)$ \\
$<1$ minimum wage & \\
1 to 3 minimum wages & $14(5.0)$ \\
4 to 6 minimum wages & $224(80.0)$ \\
$>6$ minimum wages & $33(11.8)$ \\
Education Level & $7(2.5)$ \\
Illiterate & \\
Literate (can read and write their name) & $20(7.1)$ \\
Incomplete Primary Education & $16(5.7)$ \\
Completed Primary Education & $185(66.1)$ \\
Incomplete Secondary Education & $28(66.1)$ \\
Complete Secondary Education & $5(1.8)$ \\
Incomplete Superior Education & $3(2.0)$ \\
Post-Graduate & $2(0.7)$ \\
Marital Status & $1(0.4)$ \\
Living with a companion & \\
Living with an irregular companion & $203(72.5)$ \\
Does not live with a companion & $2(0.7)$ \\
Does not have a companion & $2(0.7)$ \\
Living alone & $43(15.4)$ \\
\hline & $30(10.7)$ \\
\hline
\end{tabular}

continued...

\begin{tabular}{lc}
...continuation & $\mathbf{n}(\mathbf{\%}) \mathbf{n}=\mathbf{2 8 0}$ \\
\hline Variables & \\
\hline Occupation & $128(45.7)$ \\
Retired & $33(11.8)$ \\
Pensioner & $72(25.7)$ \\
Works at home/housewife & $2(0.7)$ \\
Unemployed & $45(16.1)$ \\
Other & \\
Religion & $224(80.0)$ \\
Catholic & $51(18.2)$ \\
Evangelican & $2(0.7)$ \\
None & $3(1.1)$ \\
Others & \\
Ethnicity & $246(87.9)$ \\
White & $6(2.1)$ \\
Mixed & $28(10.0)$ \\
Black & \\
\hline
\end{tabular}

The average age of the participants was 63.0 ( \pm 11 years), the majority were females, of white ethnicity, with incomplete primary education, living with a regular companion, retired, with family income of 1-3 minimum wages, which at the time of data collection was $\mathrm{R} \$ 545.00$.

Average diagnosis time of respondents was 12.0 years ( \pm 9.4 years). More than half of the respondents had undergone antihypertensive treatment for more than six years, and the prevalent type of treatment was the association of medication and non-medication. For antihypertensive treatment, respondents used more than three medications with daily dosage varying from two to three doses in most cases. Physical activity was barely present among respondents, $16.5 \%$ reported practicing it regularly, and $12.2 \%$ did not practice it regularly. Smoking and drinking habits were present among hypertensive respondents, $11.8 \%$ and $12.9 \%$, respectively. When asked about their opinion on the amount of salt in their diets, almost half revealed considering it little and/or poor (Table 2).

Table 2 - Data on hypertensive respondents - Criciúma, SC, Brazil, 2011.

\begin{tabular}{lc}
\hline Variables & $\mathbf{n}(\mathbf{\%}) \mathbf{n}=\mathbf{2 8 0}$ \\
\hline Diagnosis Time (Standard Deviation) & $12.0( \pm 9.4)$ \\
Treatment Time & IC $(95 \%): 10.89-13.10$ \\
$<1$ year & $9(3.2)$ \\
1 to 2 years & $18(6.4)$ \\
3 to 5 years & $56(20.0)$ \\
6 years & $22(7.9)$ \\
$>6$ years & $175(62.5)$ \\
Treatment Type & \\
Exclusively with medication & $140(50.0)$ \\
Exclusively non-medication & $2(0.7)$ \\
Medication + non-medication & $138(49.3)$ \\
\hline
\end{tabular}




\begin{tabular}{|c|c|}
\hline Variables & $n(\%) n=280$ \\
\hline \multicolumn{2}{|l|}{ Amount of medication/Day } \\
\hline One Drug & $28(10.0)$ \\
\hline Two Drugs & $64(22.9)$ \\
\hline Three Drugs & 55(19.6) \\
\hline$>4$ Drugs & $133(47.5)$ \\
\hline \multicolumn{2}{|l|}{ Dosage/Day } \\
\hline One Dose & $31(11.1)$ \\
\hline Two Doses & $124(44.3)$ \\
\hline Three Doses & $110(39.3)$ \\
\hline$>4$ Doses & $15(5.4)$ \\
\hline \multicolumn{2}{|l|}{ Use of Everyday Medication } \\
\hline Yes & $215(76.8)$ \\
\hline No & $65(23.2)$ \\
\hline \multicolumn{2}{|c|}{$\begin{array}{l}\text { Practice of Exercise ( } 3 \text { or more times a } \\
\text { week) }\end{array}$} \\
\hline Regularly & $46(16.5)$ \\
\hline Irregularly & $34(12.2)$ \\
\hline None & $200(71.3)$ \\
\hline \multicolumn{2}{|l|}{ Smoking Habits } \\
\hline Yes & $26(9.3)$ \\
\hline No & $190(67.8)$ \\
\hline Sometimes & $7(2.5)$ \\
\hline Quit & $57(20.4)$ \\
\hline \multicolumn{2}{|l|}{ Alcohol Consumption } \\
\hline Yes. every day & $3(1.1)$ \\
\hline Yes. on weekends & $33(11.8)$ \\
\hline No & $243(86.8)$ \\
\hline Quit/Has stopped drinking & $1(0.4)$ \\
\hline \multicolumn{2}{|l|}{ Amount of salt in diet } \\
\hline Normal & $112(40.1)$ \\
\hline Little/Poor & $139(49.8)$ \\
\hline Salty & $28(10.0)$ \\
\hline
\end{tabular}

Figure 1 shows the analysis of the sleeping medication compared to total score of each PSQI instrument components, which vary on a scale of 0 to 3 points and total score of the instrument vary on a scale ranging from 0 to 21 points. Data stratification of each component was conducted comparing individuals who used medication for sleeping and those who did not use them. We identified that 106 hypertensive patients used medication for sleeping, while 174 reported not using them. When comparing the averages of the components among individuals who used medication and those who did not, we found a statistical difference of $\mathrm{p} \leq 0.05$ when compared to component 1 : Subjective sleep quality. When compared to components 2: Sleep latency, 4: Habitual sleep efficiency, 5: Sleep disturbances, 6: Use of sleep medication and 7: Daytime disturbances, we observed a statistical difference of $\mathrm{p} \leq 0.01$. Component 3 : Sleep duration showed no statistical difference. In the overall score, a statistically significant difference $p \leq 0.01$ was observed when comparing the overall quality of sleep of hypertensive patients that use sleeping medication with www.ee.usp.br/reeusp those who do not.

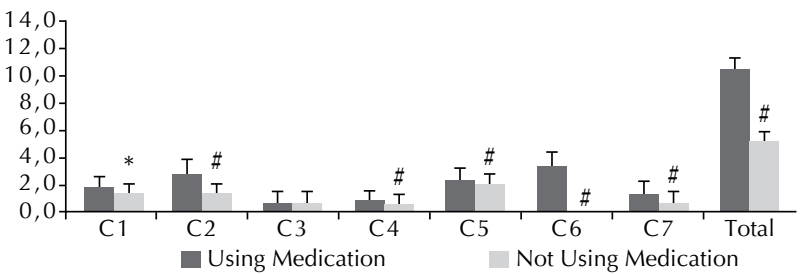

Figure 1 - Comparison of scores of each component of the PSQI instrument $x$ Use of medication for sleeping - Criciúma, SC, Brazil.

Legend: C1 - Component 1 (Subjective sleep quality), C2 - Component 2 (Sleep Latency), C3 - Component 3 (Sleep Duration), C4 - Component 4 (Habitual sleep efficiency), C5 - Component 5 (Sleep disturbances), C6 - Component 6 (Use of sleep medications), C7 - Component 7 (Daytime disturbances). Total refers to the total score of the instrument, on a scale ranging from 0 to 21 points. Statistical method employed: Mann-Whitney $U$ test. (\#: $\left.\mathrm{p} \leq 0.01 ;{ }^{*}: \mathrm{p} \leq 0.05\right)$.

Table 3 shows the relationship established between the use of medication to sleep and sleep quality. The global PSQI score showed that 156 hypertensive patients had bad sleep quality and 124 had good sleep quality. Of the 156 hypertensive who reported poor sleep quality, 97 were using medication to sleep and of the 124 who reported good quality sleep, only nine were using medication to sleep. In this analysis, when comparing sleep quality with the use of sleeping medication, the data revealed a statistical difference $(\mathrm{p} \leq 0.01)$. The probability Odds Ratio 21 (95\% CI, 9.944.54) was calculated, revealing that hypertensive patients who did not use sleeping medication were 21 times more likely to have good sleep quality in comparison to hypertensive patients using sleep medication, a statistically significant difference.

Table 3 - Relationship between medication and sleep quality Criciúma, SC, Brazil, 2011.

\begin{tabular}{lcccc}
\hline \multirow{2}{*}{$\begin{array}{c}\text { Relationship between } \\
\text { Medication and Sleep Quality }\end{array}$} & \multicolumn{3}{c}{ Quality of Sleep } \\
\cline { 3 - 5 } Total & Good & Bad & \\
\hline \multirow{2}{*}{ Use of Medication } & Does not use it & 115 & 59 & 174 \\
& Uses it & 9 & 97 & 106 \\
\hline \multirow{2}{*}{ Total } & & $\mathbf{1 2 4}$ & $\mathbf{1 5 6}$ & $\mathbf{2 8 0}$ \\
\hline
\end{tabular}

Statistical method employed: Pearson Chi-square test ( $\mathrm{p} \leq 0.001)$.

\section{DISCUSSION}

In 2010, hypertension was responsible for the highest percentage of attributable death (13\%), and the leading cause of disability, accounting for over $20 \%$ of the world rate for life years adjusted for disability in adults of 70 years of age or more, and about $15 \%$ of those between 50 and 69 years $^{(17)}$. The evidence that OSAS is a key risk factor in the development of hypertension and consequent development of cardiovascular diseases is clear ${ }^{(18-19)}$.

In all regions in Brazil, the prevalence of self-reported hypertension was higher among women, which may be partly justified by the greater use of health services by women, which provides them with the opportunity to receive a medical diagnosis of hypertension ${ }^{(20)}$.

It was found that hypertensive individuals are more likely to develop emotional disorders such as anxiety and 
depression, triggering changes in sleep, being strongly related to the hypertension risk factor for sleep disorders ${ }^{(21)}$.

Studies have indicated that the presence of untreated sleep disorders, insomnia and especially OSAS are associated with an increased risk of fatal and non-fatal cardiovascular disease ${ }^{(22)}$, showing a high prevalence of OSAS in hypertensive individuals, and on the other hand, hypertension is found in a large proportion of individuals with $\operatorname{OSAS}^{(23)}$.

Adults with hypertension had reduced cerebral circulation in areas that are normally always active, and there is compensation with the increased blood flow to isolated areas of the brain. With time, these cerebrovascular changes could manifest with cognitive or behavioral changes including sleep disturbance, making it difficult to concentrate and resulting in fatigue ${ }^{(24)}$.

A study evaluated the occurrence of OSAS in 394 hypertensive Swedish patients, revealing the occurrence of OSAS in 59\% of the studied population, but elevated blood pressure was not observed in this study ${ }^{(11)}$.

The worldwide prevalence of hypertension complaints and sleep disorders has increased in recent decades, and growing evidence suggests that the conditions of poor sleep is associated with increased prevalence and incidence of hypertension ${ }^{(25-26)}$.

It should be noted that before establishing antihypertensive treatment, investigations about the quality of sleep need to be conducted because drug therapy can influence the onset of sleep disorders in these individuals who are already more prone to them. Often the treatment of sleep dis- orders contributes to better control of blood pressure levels.

Even though the literature describes the fact that hypertensive individuals are likely to have problems related to sleep, there is a lack of attention from the public health in relation to this issue because our findings are from populations that are serviced by the public health service. Thus, it is expected that these individuals receive attention often contributing to improved overall health, resulting in the reduction of public spending on maintaining the health of this population.

\section{CONCLUSION}

Considering the results of this study, it was found that hypertensive individuals have poorer quality sleep than those with normotensive individuals, and those who use sleeping medication had poorer quality of sleep compared to hypertensive patients who did not use medication.

The incidence of respondents who used medications for sleeping was high, suggesting a true analysis of how sleep quality of these individuals was being affected, possibly significantly interfering on their quality of life.

Although our findings show that hypertensive individuals have poor sleep quality, data should be treated with caution because sleep quality was not investigated prior to the diagnosis of hypertension, nor was the sleep quality of normotensive individuals of the same health region so results could be compared. It is recommended that further studies continue to clarify these aspects due to the relevance of this topic.

\section{RESUMO}

Objetivo: Analisar a qualidade do sono de hipertensos registrados no sistema nacional de cadastramento e acompanhamento de hipertensos. Método: Estudo transversal, quantitativo e descritivo realizado com 280 usuários hipertensos cadastrados no Programa Nacional de Hipertensão e Diabetes do Governo Federal nos meses de agosto a outubro de 2011. Foram aplicados questionários que permitiram traçar o perfil sociodemográfico, dados sobre hipertensão arterial sistêmica e Índice de Qualidade de Sono de Pittsburgh. Resultados: Verificou-se predomínio da qualidade de sono ruim entre os entrevistados (156 hipertensos) e altas taxas de uso de medicações para dormir (106 hipertensos). Outro dado relevante refere-se à qualidade de sono entre hipertensos que utilizam medicação para dormir comparados àqueles que não utilizam $(p \leq 0,01)$. Conclusão: Indivíduos com hipertensão arterial sistêmica apresentam associação negativa com a qualidade do sono.

\section{DESCRITORES}

Hipertensão; Sono; Síndromes da Apneia do Sono; Saúde Pública; Avaliação em Saúde.

\section{RESUMEN}

Objetivo: Analizar la calidad del sueño de hipertensos registrados en el sistema nacional de registro y seguimiento de hipertensos. Método: Estudio transversal, cuantitativo y descriptivo, llevado a cabo con 280 usuarios hipertensos registrados en el Programa Nacional de Hipertensión y Diabetes del Gobierno Federal en los meses de agosto a octubre de 2011. Fueron aplicados cuestionarios que permitieron trazar el perfil sociodemográfico, datos acerca de la hipertensión arterial sistémica e Índice de Calidad de Sueño de Pittsburgh. Resultados: Se verificó el predominio de la mala calidad de sueño entre os entrevistados (156 hipertensos) y altas tasas de uso de fármacos para dormir (106 hipertensos). Otro dato relevante se refiere a la calidad de sueño entre hipertensos que utilizan fármacos para dormir comparados a los que no utilizan $(\mathrm{p} \leq 0,01)$. Conclusión: Individuos con hipertensión arterial sistémica presentan asociación negativa con la calidad del sueño.

\section{DESCRIPTORES}

Hipertensión; Sueño; Síndromes de la Apnea del Sueño; Salud Pública; Evaluación en Salud.

\section{REFERENCES}

1. Aounallah-Skhiri H, El Ati J, Traissac P, Ben Romdhane H, Eymard-Duvernay S, Delpeuch F, et al. Blood pressure and associated factors in a North African adolescent population: a national cross-sectional study in Tunisia. BMC Public Health. 2012;12:98. 
2. Robitaille C, Dai S, Waters C, Bancej C, Quach S, Ellison J, et al. Diagnosed hypertension in Canada: incidence, prevalence and associated mortality. CMAJ. 2012;184(1):E49-56.

3. Ferreira SR, Moura EC, Malta DC, Sarno F. Frequency of arterial hypertension and associated factors: Brazil, 2006. Rev Saúde Pública. 2009;43 Suppl 2:98-106.

4. Marin MJS, Santana FHS, Moracvick MYAD. The perception of hypertensive elderly patients regarding their health needs. Rev Esc Enferm USP [Internet]. 2012 [cited 2014 Dec 10];46(1):103-10. Available from: http://www.scielo.br/pdf/reeusp/v46n1/en_v46n1a14.pdf

5. Borges JW, Pinheiro NM, Souza AC. Hypertension communicated and hypertension understood: nursing know-how and practices in a Family Health Program in Fortaleza, State of Ceará. Ciênc Saúde Coletiva. 2012;17(1):179-89.

6. Sant'Anna MP, Mello RJ, Montenegro LT, Araújo MM. Left and right ventricular hypertrophy at autopsy of hypertensive individuals. Rev Assoc Med Bras. 2012;58(1):41-7.

7. Nascente FM, Jardim PC, Peixoto MR, Monego ET, Moreira HG, Vitorino PV, et al. Arterial hypertension and its correlation with some risk factors in a small Brazilian town. Arq Bras Cardiol. 2010;95(4):502-8.

8. Costa C, Santos B, Severino D, Cabanelas N, Peres M, Monteiro I, et al. Obstructive sleep apnea syndrome: An important piece in the puzzle of cardiovascular risk factors. Clin Investig Arterioscler. 2014 Dec 10. [Epub ahead of print]

9. Lévy P, McNicholas WT. Sleep apnoea and hypertension: time for recommendations. Eur Respir J. 2013;41(3):505-6.

10. Dudenbostel T, Calhoun DA. Resistant hypertension, obstructive sleep apnoea and aldosterone. J Hum Hypertens. 2012;26(5):281-7.

11. Broström A, Sunnergren O, Årestedt K, Johansson P, Ulander M, Riegel B, et al. Factors associated with undiagnosed obstructive sleep apnoea in hypertensive primary care patients. Scand J Prim Health Care. 2012;30(2):107-13.

12. Castro Júnior JR, Fernandes N, Lacet TB, Maia FS, Bonato GR, Nogueira C, et al. Total body water reduction in subjects with chronic kidney disease on peritoneal dialysis is associated with a better hypertension control. J Bras Nefrol. 2014;36(4):482-9.

13. Anunciato IF, Lobo RR, Coelho EB, Verri WA Jr, Eckeli AL, Evora PR, et al. Big endothelin-1 and nitric oxide in hypertensive elderly patients with and without obstructive sleep apnea-hypopnea syndrome. Arq Bras Cardiol. 2013;101(4):344-51.

14. Haack M, Serrador J, Cohen D, Simpson N, Meier-Ewert H, Mullington JM. Increasing sleep duration to lower beat-to-beat blood pressure: a pilot study. J Sleep Res. 2013;22(3):295-304.

15. Ji-Rong Y, Hui W, Chang-Quan H, Bi-Rong D. Association between sleep quality and arterial blood pressure among Chinese nonagenarians/centenarians. Med Sci Monit. 2012;18(3):PH36-42.

16. Turek NF, Ricardo AC, Lash JP. Sleep disturbances as nontraditional risk factors for development and progression of CKD: review of the evidence. Am J Kidney Dis. 2012;60(5):823-33.

17. Modesti PA, Perruolo E, Parati G. Need for better blood pressure measurement in developing countries to improve prevention of cardiovascular disease. J Epidemiol. 2014;25(2):91-8.

18. Denker MG, Cohen DL. Use of continuous positive airway pressure for sleep apnea in the treatment of hypertension. Curr Opin Nephrol Hypertens. 2014;23(5):462-7.

19. Sampaio RS, Pereira MG, Winck JC. Adaptation of the sleep apnea quality of life index (SAQLI) to Portuguese obstructive sleep apnea syndrome patients. Rev Port Pneumol. 2012;18(4):166-74.

20. Muniz LC, Cascaes AM, Wehrmeister FC, Martínez-Mesa J, Barros AJ, Menezes AM. Trends in self-reported arterial hypertension in Brazilian adults: an analysis of data from the Brazilian National Household Sample Survey, 1998-2008. Cad Saúde Pública. 2012;28(8):1599-607.

21. Gangwisch JE, Malaspina D, Posner K, Babiss LA, Heymsfield SB, Turner JB, et al. Insomnia and sleep duration as mediators of the relationship between depression and hypertension incidence. Am J Hypertens. 2010;23(1):62-9.

22. Santos-Silva R, Castro LS, Taddei JA, Tufik S, Bittencourt LR. Sleep disorders and demand for medical services: evidence from a populationbased longitudinal study. PLoS One. 2012;7(2):e30085.

23. Budhiraja R, Budhiraja P, Quan SF. Sleep-disordered breathing and cardiovascular disorders. Respir Care. 2010;55(10):1322-32.

24. Cha SD, Patel HP, Hains DS, Mahan JD. The effects of hypertension on cognitive function in children and adolescents. Int J Pediatr [Internet]. 2012 [cited 2014 Dec 10];891094. Available from: http://www.ncbi.nlm.nih.gov/pmc/articles/PMC3299290/

25. Bruno RM, Palagini L, Gemignani A, Virdis A, Di Giulio A, Ghiadoni L, et al. Poor sleep quality and resistant hypertension. Sleep Med. 2013;14(11):1157-63.

26. Palagini L, Bruno RM, Gemignani A, Baglioni C, Ghiadoni L, Riemann D. Sleep loss and hypertension: a systematic review. Curr Pharm Des. $2013 ; 19(13): 2409-19$.

Acknowledgements: The authors acknowledge Jose Antonio Grande for his critical review of the article and his suggestions; and Kristian Wood for the important collaboration. 